\title{
Transatlantica
}

Revue d'études américaines. American Studies Journal

\section{Bernard Vincent. The Transatlantic Republican, Thomas Paine and the Age of Revolutions.}

Amsterdam: Rodopi B. V. Amsterdam Monographs in American Studies, 2005. 178 pages, ISBN : 90-420-1614-0.

\section{Caroline Belan}

\section{(2) OpenEdition}

\section{Journals}

Édition électronique

URL : http://journals.openedition.org/transatlantica/602

DOI : $10.4000 /$ transatlantica.602

ISSN : $1765-2766$

Éditeur

AFEA

Référence électronique

Caroline Belan, « Bernard Vincent. The Transatlantic Republican, Thomas Paine and the Age of Revolutions. », Transatlantica [En ligne], 1 | 2006, mis en ligne le 25 mars 2006, consulté le 29 avril 2021. URL : http://journals.openedition.org/transatlantica/602 ; DOI : https://doi.org/10.4000/ transatlantica.602

Ce document a été généré automatiquement le 29 avril 2021.

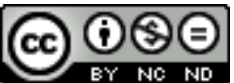

Transatlantica - Revue d'études américaines est mis à disposition selon les termes de la licence Creative Commons Attribution - Pas d'Utilisation Commerciale - Pas de Modification 4.0 International. 


\title{
Bernard Vincent. The Transatlantic Republican, Thomas Paine and the Age of Revolutions.
}

\author{
Amsterdam: Rodopi B. V. Amsterdam Monographs in American Studies, \\ 2005. 178 pages, ISBN : 90-420-1614-0.
}

Caroline Belan

1 «That Thomas Paine was a pioneer, a prophet, a visionary is something that cannot reasonably be denied» [137]. It is true that one of Bernard Vincent's greatest achievements in The Transatlantic Republican, Thomas Paine and the Age of Revolutions, is to manage to convince the reader of the exceptional character and influence of Thomas Paine not merely through the American Revolution process but also throughout a whole period of dramatic changes and conflicts and during the emergence of new and modern theories and concepts. The book is divided into two parts, «Paine, America and France, » and « Paine and the Enlightenment, » and into eleven chapters, each focusing on a precise aspect of Paine's political, social or religious environment and on his contribution to the Revolutions on both sides of the Atlantic.

2 Paine is utterly incredible-extra-ordinary-according to Bernard Vincent, as his apparent admiration for the life of the Anglo-Franco-American pervades the book. Several points should be noticed in Vincent's work. The first chapter, for example, "The Strategy of Time in Common Sense, " stands out as being more 'literary' than the rest of the book. As Vincent tries to find answers to the incredible success-«the biggest publishing success of the eighteenth century "-of Common Sense, he demonstrates how Paine's work as well as his use of the notion of time-«'Tis time to part »-《 were clearly the main ingredients in which the action of time was transmuted by some instantaneous alchemy into action upon time» [22]. Vincent's study of the past, present and future is cleverly unfolded : he shows how Paine rejected the past by rejecting tradition; « Precedent is not law. There is no such thing as an authority of the past » [25] claimed Paine, thus creating a passage to chapter VII on universal suffrage and the controversies between Paine and Edmund Burke precisely opposing tradition 
and modernity, the past and the future. Based on a precise text therefore, chapter I revolves around the study of vocabulary and themes more than the rest of the book.

Indeed most of Part One and the whole of Part Two are, with the exception perhaps of chapter VIII, "Paine's Agrarian Justice and the Birth of the Welfare State," presentations of the context in which Paine evolved as a revolutionary, a citizen or a politician. A striking point is to realize that Paine, though born British and made a French and American citizen, was ultimately rejected by the three countries as a result of the Terror upheavals in France, or merely because of Paine's own controversial attitude and writings in America and Britain. For instance, Vincent explains, Paine's contribution to the French revolution almost backfired on him as he was jailed for his being a foreigner, British precisely, which beats all when one knows he had been banished from his native country. This shows how Vincent's book is built : each chapter is full of anecdotes which, apart from being sometimes juicy, help understand in a clear and simple way the context in which Paine evolved and the teeming of ideas triggered off by the changes he witnessed in Europe and in America.

4 Vincent's book, therefore, should be considered as an indispensable tool to study the American Revolution and its impact on Europe, or simply Thomas Paine as a writer and an American character-indeed The Transatlantic Republican clarifies and widens the ideas, ideals, interactions and conflicts between France, Britain and America. The book is written in a simple, efficient manner and undoubtedly reaches its goal. Moreover Bernard Vincent, like Paine apparently, is not deprived of humor and some anecdotes or puns are truly delectable : " The immediate beheading of Louis Capet was passed by a majority of one vote [...]. While the consequences of the vote were quite unpleasant for the King himself, they were also disagreeable to Thomas Paine, though to a lesser degree » [88]. They were indeed.

5 The only objection one could make about the book is actually involuntarily made by Vincent himself. Chapter II is thus introduced: «Though not specifically focused on Paine, this chapter may serve to better understand the political, cultural and cosmopolitan setting in which Paine [...] moved and acted [...] » [65]. Chapter II on the Masonic Order is conceived in the same way and finally informs the reader that Paine... was not a Mason. Every bit of information in this book is precious; Paine, whether out of touch with reality in France or in harmony with history in America, was the product of an era and of his environment. What destabilizes the reader is not the contents of the book; it is its title as one expects-wrongly probably-a biography focusing on Paine and Europe. What the reader gets is much more than that and may Bernard Vincent be thanked for it. Understanding Thomas Paine by understanding his world is what the book is all about. 


\section{AUTEUR}

CAROLINE BELAN

Université de Rouen 